
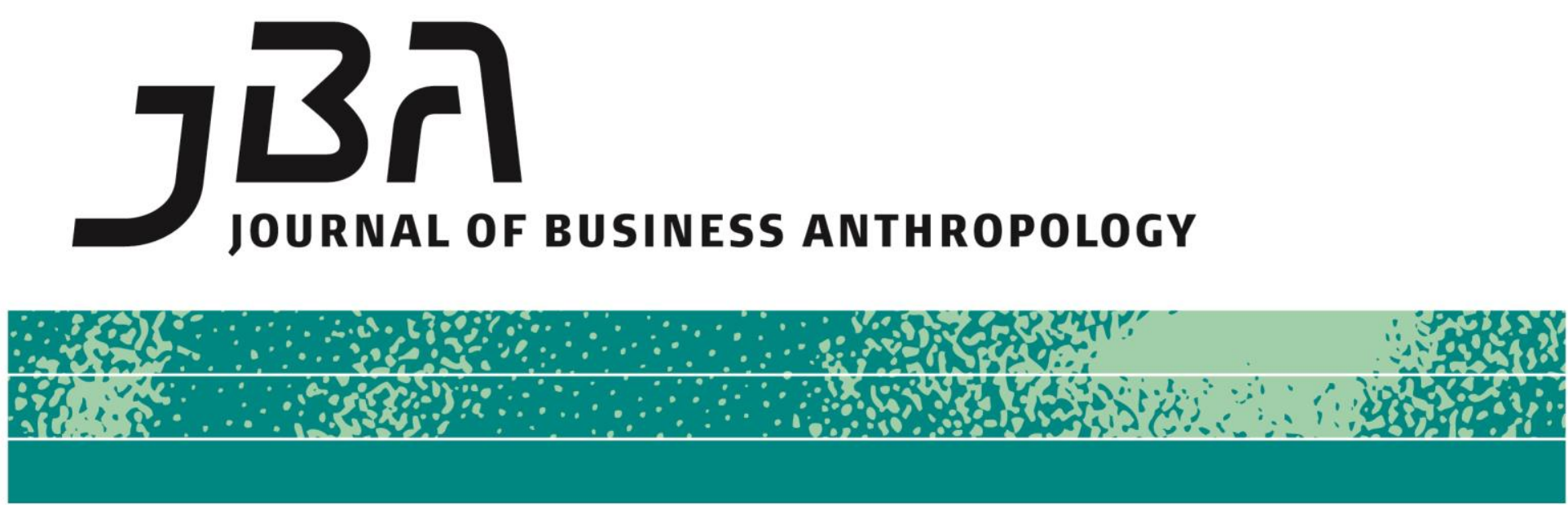

\title{
The Anthropology of Business Ethics: Worth Thinking about!
}

Ghislaine Gallenga

\begin{abstract}
This article deals with epistemological thoughts about business ethics. My intention is to consider business ethics as a research subject in anthropology and not to judge the relevance of the morality or ethics: in other words, the integration of activities in a "common good" category. The article examines the philosophical ground of this notion and explores whether business ethics is related to this philosophical background. While, from an anthropological point of view, it is better to draw a value judgment from the notion of "business ethics" (applicability, truthfulness, intentionality, and so on), the argument presented here is that it is better to consider "business ethics" as a category of work management at the meeting point between theory and practice, and to observe in situ how this notion is used, articulated and circulated in the daily life of a workplace.
\end{abstract}

\section{Keywords}

Anthropology, Epistemology, Business ethics, Ethics, Morality, Corporate culture
Page 1 of 13

JBA Special Issue 3: 7-19, Spring 2016

(C) The Author(s) 2016 ISSN 2245-4217

www.cbs.dk/jba 


\section{Introduction}

It might be assumed that anthropology is inherently wary of ethics and morality and is inclined to avoid it in the name of cultural relativism. ${ }^{1}$ As a matter of fact, the issue of the ethics or morality of anthropology has been around since the discipline emerged, although not addressed in the same terms as today. The work put together by Pat Caplan-even though it dates back a decade-draws a picture of discussions and dilemmas around ethics in anthropology and asks the question: "What is anthropology for? Who is it for?" (2003: 3) and re-examines the relationships between the discipline and ethics since the 1960s (ibid.: 127). Moreover, a rejection of anthropology and the knowledge of anthropologists being used for espionage or military purposes has marked the history of the discipline from Franz Boas (1919) to Marshall Sahlins $(2007 ; 2013)$. More recently, an attempt to create a new field, named-depending on its authors-an "ethnography of moralities" (Howell 1997), "moral anthropology" (Fassin 2008), "anthropology of moralities" (Zigon 2008) and anthropology of ethics (Massé 2009; Faubion 2011), seems to transcend the question of relationships between anthropology and the legitimacy of its practice.

May Edel and Abraham Edel (2000 [1968]) have opened a dialogue between philosophy and anthropology in an interdisciplinary approach and concluded, unsurprisingly, that both disciplines have benefitted symbiotically from one another, thus enabling an exploration both of how the theory of ethics is redefined when its cultural content becomes obvious and of the relations between morality and cultural schemes.

Today, ethics is an expression of the relationship with "what is happening." Ethics refers to the practice of regulating and shaping our comment on historical, technical and scientific, social or media situations. This norm regarding comments and opinions is embodied by institutions with their own authority such as the "national ethical commissions" appointed by the State (Badiou 2003: 20). We are also witnessing an inflation of ethics (Canto-Sperber 2006) to such an extent that they are found, as if fragmented, in several fields, so that there are now an ethics of the workplace, business ethics, medical ethics, space ethics, and so on (see Marzano 2008). Parallel to this fragmentation of ethics into specialized domains, we are witnessing the emergence of a new professional category in the social division of work, whose representatives call themselves "ethicists" to distinguish themselves from thinkers of moral philosophy; these are "practitioners" of ethics (CantoSperber and Ogien 2006: 14).

${ }^{1}$ This article is a revised version of a paper published in the review Moussons, 2013, $n^{\circ} 21$, 21-36. 
Naturally, business ethics must consider the phenomenon of the social inflation of ethics in the world of work, especially as ethics and anthropology deal with similar issues and concerns. Not wishing to make morality or ethics my central subject of study (Fassin 2008), which would mean having "the ambition of making explicit and intelligible the evaluative principles and practices in different societies and contexts, of analysing and interpreting the way social agents form, justify and apply their judgements about good and evil" (Fassin and Stoczkowski 2008: 331), I wish to deal with the notion of "business ethics" in its emic meaning, as it is used by actors within the corporate world.

Business ethics can be understood as the construction of norms and values that have been made clear, that meet social demand, and that are used to formalise the principles of collective work (Cardot 2006). However, such a definition brings the notion of "business ethics" closer to that of "corporate culture." Both notions refer to moral rules spelt out by the leaders of a company to legitimise work management and establish their corporate image (Cuche 2004: 99). I do not consider business ethics as simply the laying out and carrying out of these values. Business ethics is not simply a set of guidelines and ethical codes. It is also about how these values are received, embraced, manipulated, utilized, or evaded by participants in a specific business organization, be they managers, employees, contractors, or customers.

Research carried out so far, mainly in the fields of management or applied ethics, takes into account the moral aspect of companies in the normative sense: is the subject of these works "actually" moral or are their practices morally acceptable? How can production be moralised? However, these studies do not really look into "business ethics" as such: in other words, when a company displays, promotes and codifies values as if they were an object of its own. Hence, Browne and Milgram (2009) explore the moral part of economy in the companies they have observed. Others have attempted to tackle the moral side of the economy (Browne 2009: 1) or the concept of moral economy, as defined by Andrew Sayer (2005).

In this article, then, I shall explore the notions of morality, ethics and business ethics. The last should not be automatically understood as a category of analysis, for it is related to discourse and used as a managing tool by businessmen or managers. Thus, business ethics encounters an increasing social demand for responsibility from companies, which should act as role models for society and make their inner workings more humane. However, without judging the relevance of morality or ethics within companies, I will explore the conditions that can make business ethics possible while avoiding, in the debate on ethics, the normative question of their application.

My suggestion is that we go back to the philosophical roots of the notion. To do this, I will first examine the concept as defined by the 
philosophers of business ethics, which will lead me to present a program for an anthropological reading of such ethics. My point is neither to speak as a moralist nor to perform a moral evaluation of the corporate world. Naturally, organizational anthropology must deal with the social phenomenon of the increasing importance of ethics in the world of work, even more so because moral philosophy through ethics and anthropology share similar issues. I shall focus on "business ethics" as a subject by looking at its historical background and its social uses.

\section{Philosophy versus anthropology}

The word "ethics" comes from the Greek for "to inhabit" or "to inhabit the world," or ethos: habits, customs, in the general sense of behaviour. For the Greeks, it refers to a form of knowledge as to how to behave. Morality is a word of Latin origin, from Latin mos (or mores in the plural) and also means "customs." Morality is indeed the classical Latin translation of what the Greeks call "ethics." Clearly, ethics and morality both deal with the definition and description of the categories of good and evil translated into values, but also into individual behaviour. For most authors, both words seem to be used as synonyms. However, a difference gradually appeared in the use of both terms. In more recent times, it has often been considered that the term "morality" should be reserved for values inherited from the past and tradition, or from religion. "Morality more or less evolved into 'what is transmitted,' becoming a code of behaviours that were already more or less set" (Droit 2009: 19). Today, however, the term "ethics" is more widely used in fields in which norms and such behaviours are being constructed by means of individual or collective reflection. Morality is thus related to acquired norms, while ethics involves the construction of norms made necessary by ongoing changes (ibid.: 20-21). "Ethics has become the name of morality in the making" (ibid.: 22). A similar distinction is made by Monique Canto-Sperber and Ruwen Ogien (2006). In other terms, they are both the same substance, "the ethical substance" as Michel Foucault puts it (1984), at two different stages of its production/reproduction.

Issues related to the links between Nature and Culture, between universalism and particularism, the relationship to the otherness, and so on, confirm that such concerns are shared. At the end of the day, ethical issues raised by moral philosophers appear to be the theoretical questioning of social anthropologists. As a matter of fact, both disciplines have become the target of a common social demand when it comes to tackling bioethical dilemmas, the universality of Human Rights, moral conflicts in situations where "cultures" coexist, and so on.

The diversity of moralities thus constitutes one of the cornerstones of philosophy, just as anthropology claims that its epistemological foundations are diverse. Isaiah Berlin (1969) favours the notion of "moral pluralism," and he champions the idea that there is no single value 
system. The meaning given to ethics today bears a reference to Human Rights-rights that are assumed to be natural-in the same way as some essentialist assumptions of anthropology are meant to be universal. Such assumptions claim to make a distinction between cultural relativism and moral relativism in order to put the former on a pedestal in the name of a certain kind of ethics, while banning the latter from society. Are ethics natural? And are they universal? Clearly, these questions are issues for both moral philosophy and anthropology, as both disciplines operate within a vaguely defined scope in which there is tension between universalism and relativism. ${ }^{2}$

However, unlike the moral philosopher, the anthropologist is uncomfortable suggesting the existence of a universal morality. Could we possibly go beyond the empirical observation that there is a variety of ethics in different places and eras, all equally valid, all being the expression and the outcome of human societies? Is it really the role of the anthropologist to assume the superiority or validity of one morality/ethics over another? How arbitrary is this assumption, which results from a surgical thinking process that restricts the contours of "Morality" and acts as a substratum unrelated to the context of a given culture? Isn't this position the expression of a fear that, in the name of cultural relativism, one may conclude that "ethics do not exist" (Badiou 2003: 53)? If such ethical questioning carries universalism at its very heart, it seems relevant to try and test this universality, which always appears relative to specific cases, in order to examine how ethics become specific to a particular cultural background or to a variety of fields of human activities within a certain cultural context (in Indonesia, in France, in India, in a grocery store, in a public company, in social work).

Ethics, as understood today, are an exercise in "consensual legislation" for human beings, for their needs, their lives, their deaths, or for an obvious and universal definition of what is evil and what does not suit human nature (Badiou 2003: 25). For Kant, ethics are seen as the ability to distinguish Evil (for in the modern use of ethics, what is evil or negative comes first, thus implying a consensus of what is "barbarous," and freedom of opinion means the freedom to identify Evil) (ibid.: 27-28). It is assumed that there exists one general human subject and that the evil that happens to them can be identified through universal criteria. "As ethics considers Evil to be inherently negative, it effectively refuses to address the singularity of a situation" (ibid.: 36). Good, in contrast, allows us to define evil, not the other way around (ibid.: 38). The main difficulty in ethics is to adapt a rule meant to be universal and unspecific-that is to say, a Law-to an individual's behaviour. This difficulty of the dialectics

\footnotetext{
${ }^{2}$ One of the factors that may explain the relative lack of interest in anthropological studies of morality by a generation of American anthropologists after World War II is the intense debate surrounding cultural relativism and universalism that took place within the American Anthropological Association following publication of the United Nations' Declaration of the Rights of Man in 1948.
} 
between universalism and particularism is also found in anthropology, which is probably more affected in its episteme than is moral philosophy. This constant oscillation between ethical thinking and anthropology is full of pitfalls and bias that the anthropologist must avoid for fear that he or she might become a moralist.

Moreover, it is difficult to consider ethics as a universal category, even though it is based on universalist concerns, because it is also based on some form of culturalism (ibid.: 51). In the name of "universal" ethics, one should acknowledge and embrace this difference, while simultaneously ignoring it. As Badiou points out (ibid.: 39), "from the start, ethics are the ethics of others." Ethics are the main opening to the other, they subordinate identity to difference. Ethics conquer distance in a way that could be summed up by saying: be like me and I shall respect your difference. The real question is therefore "recognizing the same" (ibid.: 49). Very few scholars have managed to solve this contradiction. Indeed, one may wonder if it is possible to address ethics, or the plurality of ethics, in an ethical way without falling into the pitfall of blind universalism, denying the difference of value systems associated with well-being or the pitfall of scientific cynicism that denies the universality of suffering-a moral truth of our times-in the name of intended scientific objectivity. Ethics, therefore, carries with it an inherent paradox: it tends to standardise behaviour on the basis of an ostensible universality, while representing a mere contradiction between tolerance and tensions of identity (ibid.: 44). If ethical questioning and anthropology have a common origin (the tension between universalism and singularity, the questioning of Man's humanity when confronted with otherness), their paths-and, arguably, their destinations-are different. When anthropology deals with morality or ethics, it is not supposed to be in their applied form (Fassin 2008).

For anthropologists, one solution may be to relinquish a fixed approach to ethics and morality in favour of a dynamic approach in which there is no "one size fits all" ethics, but "ethics in progress" (Badiou 2003: 38), or, to repeat a phrase used above, ethics "in the making." Rather than putting moral differences on trial, anthropologists should address and observe the process of morality-a process during which the individual or the collective deals with the possibilities of a situation, with the constraint of recollecting and reinterpreting what is transmitted (morality) in order to create (ethics). The multiplicity of processes by which ethics is produced should be addressed within a specific context.

But how do the emergence and development of "business ethics" fit into these questions? Before establishing whether the anthropologist is confronted with an ethical or a moral issue, one should take a closer look at "business ethics" as a subject by placing it against its historical background and social uses. Is business ethics the daily construction of an ethical position, or is it a new language for the corporate world, reflecting 
the rise of moral categories in today's semantics and politics? Does the language of business ethics encompass the reality that it strives to show; that described by the philosophical discourse from which anthropologists draw their definition of ethics? This issue should not be addressed in normative but in pragmatic terms. Where is "business ethics" to be found in the production process? How does it address production itself? Where is business ethics found in production relations between workers and/or managers? How is it used in the company's daily life? All these questions are possibilities for fruitful research in the field of the anthropology of entrepreneurial ethics, but this article is not intended to answer these questions definitively. Rather, let us review the history of the notion of an explicitly "business ethics."

\section{Anthropology versus business ethics}

With its roots in the 1970s, business ethics emerged in the 1990s when companies started caring more about their social image while simultaneously trying to demonstrate that their efforts towards costeffectiveness were compatible with social or environmental justice and respect for individual rights. Business ethics then appeared in the field of applied ethics-the latter not being ethics as understood by moral philosophy, but a mere "guide." All professions are underpinned by values and principles that can clash with ethics. In the corporate world, this "reflection" has led to the drawing up of charters and codes of conduct by which employees should abide.

We could ask ourselves whether obeying these various codes of conduct and charters under managerial pressure within a company (to avoid redundancy, for example) has to do with the notion of "ethics" as understood by moral philosophy. For Kant, an act is moral when performed out of duty and pure respect for moral law. Unlike the sense of duty, it is an applied constraint. The expression "ethics committee," describing a group of people in charge of safeguarding the application of ethics by scientists, soon sounds like an oxymoron. If ethics are codified, defined, or even imposed by an external governing body, hence becoming a constricted duty, are we still in the field of ethics?

One of the main differences between business ethics and discussions of ethics and morality lies in the fact that such discussions are an attempt to solve moral conflicts, to define what is good or fair.

Business ethics, however, does not deal with such principles. It belongs to the post-discussion phase, as if an original assumption has already been made, although no mention is made of how or by whom such decisions have been done so. In the light of this consensus, employees and customers must follow ethics as an order. Individuals must comply with moral imperatives without discussing them before or afterwards. Whereas customers can somehow take a stand on these notions of "good" and "fair" that underlie business ethics, by choosing one company over 
another, this is not the case for employees, who are caught up in a system in which they have no say. Does ethics not require, as theorists state, the independence of autonomous subjects and an examination of conscience? Is ethics under an employer's authority still ethics?

For Monique Canto-Sperber, the role of moral philosophy is to make sure that a debate on ethics does not just result in a series of rules or guidelines to be followed-which would amount to merely imposing moral standards-but in recommendations that have been discussed thoroughly and whose motives and conditions have been made clear (2012: 198). In a business, however, ethics are imposed from above. Working groups may be organised ahead of time, giving employees the illusion that they are part of the decision-making process. In this respect, business ethics is not the same as ethics as defined by moral philosophy.

It seems relevant to emphasize the necessary distinction in anthropology between things pertaining to the professional ethics of the businessman and this category of "business ethics"-which probably makes more sense on the emic level. According to Monique Canto-Sperber and Ruwen Ogien (2006: 8), "professional morality can be seen as a concrete manifestation of the fact that professions [...] go along with inherent values and principles." Professional ethics is, therefore, the application of such morality by a given participant. The category of professional ethics applies to individuals immersed in the working world rather than to working collectives of large companies.

Most of the "business ethics" literature is based on the idea that "ethics pays off" and that the expected rewards for a company's good conduct will justify the money and staff invested in it. For Michela Marzano, "ethics is comparable to advertising: it sells and draws the public's attention" (2008: 117). By spelling out its own rules, "an ethical company frees itself from both morality and politics. With its statements, charters and codes, it gradually places itself above any external body likely to decide on its responsibilities" (ibid.).

Business ethics can be seen as legitimate but paradoxical because it suggests that business and ethics are incompatible. There is a confusion between the end and the means, along with a newfound difference between the ethics of economic life and the ethics of business enterprises. It stays only one step away from "cynical manipulation."

Anthropologists who carry out research in the workplace increasingly encounter similar conflicts in which codes of ethics are put forward in the production process, as well as in the collective organisation of work. What is called "business ethics" is now found everywhere. But how can it be conceived intellectually? What does this concept include? How can it be thought of in anthropological terms?

Firstly, it can be established that, in the same way that the concept of "business ethics" seems incompatible with a philosophical acceptation, 
it is not an anthropological category either. However, there are practices, codes and theories that anthropologists have a duty to question regardless of their purpose. There is a major difference between how this notion is used in practice, that is, in managerial discourse, and how it is used in philosophy and anthropology. For theorists and anthropologists, ethics is an intellectual exercise, a meaning-building process, a mode of producing moral subjects, or a research question. For the business world, however, ethics is an analytical and managerial tool, immutable and preconceived. It is therefore relevant to redefine "business ethics" as an empirical object and not as an intellectual notion, within the context of its own background and usage. However, to anthropologists, what is named "business ethics" by the actors can be studied in its emic sense, by describing how it is being used.

As a matter of fact, the period that saw the field of business ethics emerge and develop has been identified as a "global turning point," according to Caillé and Dufois (2013: 9). It was indeed in the 1970s that the idea of globalisation emerged and started to take hold. Can business ethics be interpreted as a response to the loss of normative bearings, disorganisation, a lack-or conversely, an excess-of meaning in a globalised world? Could the promotion of business ethics, or at least the social needs from which it arose, be an expression of a search for meaning in the context of a crisis of values?

Moreover, there is something paradoxical about this increasing importance of ethics: while it aims at making people more responsible, it has the opposite effect in so far as it is ethical charters that now guide people's thoughts and behaviour. Do such charters really promote autonomous thinking? Ethics can answer questions such as "How should I act?" But business ethics does not pose questions such as "What should one think?" It tells people "how they should think."

Can business ethics be considered as merely synonymous with-or an extension of-the much-talked-about corporate culture? If so, within a company, ethics would aim to negate differences between employees, thus imposing-while pretending to respect differences-a unified "corporate culture," that is, identical behaviours. It appears legitimate to think that business ethics is a supporting tool for corporate culture within the context of organizational development. Business ethics is a framework of principles of intervention aimed at a planned organization of how companies function.

Followers of business ethics, in the manner of those who promote the idea of "corporate culture," consider ethics as well as culture as an asset, a resource that can be used to manage through symbols. However, it is within the context of negotiation that ethics are played out, and it is these conflicts of loyalty-between personal ethics and the organization's ethical code-that can be a fruitful research object for the anthropologist. Such attempts to make sense of things in production units collide with the 
reality of the institution and the network of procedures and obligations in the business world. Along with an attempt to artificially create an idea of group cohesion through the notion of "corporate culture," there is an attempt to instill the ideas of "well-being" and humane management at work.

Is "business ethics" a way of avoiding "stress" at work? Does it really have the objective of applying morals to the production process, and is it capable of doing so? If so, it would be merely corporate culture. Consequently, ethics in the workplace would be relevant if the new reality of a business (as a network of production rather than as a physical unit of production) were taken into account and not reduced to the ethics of its employees or to the application of common standards of morality (CantoSperber 2012: 120). Business ethics would then come into conflict with the "invisible hand" and freedom.

Furthermore, it has become fashionable to consider a business as an entity that reflects values. Behind such practical approaches and slogans, there is a wealth of literature aimed at drawing businesses into a virtuous circle of "social performance." As a result, the thin line between the end and the means becomes blurred because of newfound differences between the ethics of economic life and the ethics of the workplace.

Business ethics is supposed to save businesses from the classic economic paradigm whereby the business world and the world of ethics were to be kept separate, in a kind of peaceful coexistence between profit and ethics. These benevolent intentions may well have originated from a will to free the business world of society's moral judgements.

\section{Conclusion}

As I have here demonstrated, business ethics is a polysemic term.

Anthropology has the right to use the notion of business ethics, but on the condition that it make a distinction between the empirical object and the philosophical notion of ethics. What we call "business ethics" fits into a corpus of technical and administrative procedures in business management that produces effects that are contrary to their own fundamental values. As business ethics attempts to create meaning, it comes up against the technicality of administrative and managerial procedures of the business world.

The anthropology of "business ethics" requires that the concept be deconstructed and subsequently "anthropologized." Having explained how anthropology is concerned with morality and ethics, it is relevant to wonder what anthropology could bring to the study of ethics in the specific context of business. "Business ethics"-like "corporate culture"-seems to be another avatar of the conceptual migration between the social sciences and philosophy, on the one hand, and the managerial line, on the other. 
In order to be approached anthropologically, the notion of "business ethics" should be viewed separately from any consideration of its purpose, applicability, or even the question of the "real" or imagined intentions of participants using them for other purposes. In short, "business ethics" should be considered as a category of work management at the meeting point between theory and practice, in order to observe how this notion is used and disseminated in the daily life of a workplace. In other words, the discussion of, ethics should be freed from any attempt to apply its results and from normative debate. An easy

solution would be to circumvent the question of "business ethics" in order to avoid the difficulty of talking about ethics without talking about ethics. However, not only is business ethics part of the daily life of the workplace, it also gives anthropologists food for thought. This is worth thinking about!

\section{References}

Badiou, A. 2003. L'éthique. Essai sur la conscience du mal. Caen: Nous.

Berlin, I. 1988 (1969). Éloge de la liberté. Paris: Calmann-Lévy.

Boas, F. 1919. Correspondence: scientists as spies. The Nation 109, No. 2842 (December).

Browne, K. E. 2009. Economics and morality : introduction. In K. E. Browne and L. B. Milgram (eds.), Economics and morality: anthropological approaches. New York: SEA Monographs, 1-40.

Browne, E. K. and B. L. Milgram (eds.), 2009. Economics and morality: anthropological approaches. New York: SEA Monographs.

Caillé, A. and S. Dufoix (eds.) 2013. Le tournant global des sciences sociales. Paris: La Découverte, coll. « Bibliothèque du MAUSS ».

Canto-Sperber, M. and R. Ogien 2006. La philosophie morale. Paris: PUF, coll. Que sais-je?

Canto-Sperber, M. 2012. Des valeurs partagées par toutes les cultures. Rencontre avec Monique Canto-Sperber, Propos recueillis par Catherine Halpern, La morale. Éthique et sciences humaines. Auxerre, Sciences Humaines Éditions, 196-202.

Caplan, P. (ed.) 2003. The ethics of anthropology: debates and dilemmas. London and New York: Routledge.

Caplan, P. 2003. Introduction: anthropology and ethics. In P. Caplan (ed.), The ethics of anthropology: debates and dilemmas. London and New York: Routledge, 1-34.

Cardot, F. 2006. L'éthique d'entreprise. Paris: PUF, coll. Que sais-je ?

Cuche, D. 2004 [1996]. La notion de culture dans les sciences sociales. 
Paris: La Découverte.

Droit, R.-P. 2009. L'éthique expliquée à tout le monde. Paris: Seuil.

Edel, M. and A. Edel 2000 [1968]. Anthropology and ethics: the quest for moral understanding. NY: Transaction Press.

Fassin, D. and W. Stoczkowski 2008. Should anthropology be moral? A debate. Anthropological Theory 8: 331.

Fassin, D. 2008. Beyond good and evil? Questioning the anthropological discomfort with morals. Anthropological Theory 8 (4): 333-344.

Fassin, D. 2010. La raison humanitaire. Une histoire morale du temps présent. Paris: Éditions de l'EHESS.

Faubion, D. J. 2011. An anthropology of ethics. Cambridge: Cambridge University Press.

Foucault, M. 1984. Histoire de la sexualité II. L'usage des plaisirs. Paris: Gallimard.

Heinz, M. (ed.) 2009. The anthropology of moralities. New York, Oxford, Berghahn Books.

Howell, S. (ed.) 1999. The ethnography of moralities. London \& New York: Routledge.

Marzano, M. 2008. L'éthique appliquée. Paris: PUF, coll. Que sais-je ?

Massé, R. 2009. Présentation: l'anthropologie face à la morale et à l'éthique. Anthropologie et Sociétés 33 (3): 7-19.

Sahlins, M. 2007. Marshall Sahlins on anthropologists in Iraq (an Open Letter to the New York Times).

http://savageminds.org/2007/10/11/marshall-sahlinsonanthropologists-in-iraq/ accessed 27 November 2011.

Sahlins, M. 2013. "A protest resignation." Interview with Serena Golden. Inside Higher Ed. February 25, 2013. https://www.insidehighered.com/news/2013/02/25/prominentanthropologist-resigns-protest-national-academy-science .

Sayer, A. 2005. The moral significance of class. Cambridge: Cambridge University Press.

Zigon, J. 2008. Morality: an anthropological perspective. Oxford: New York, Berg. 
Ghislaine Gallenga is a social anthropologist whose research has focused both on the anthropology of firms (including comparative research in the field of public service) and on reflexive anthropology (working on epistemological issues arising from ethnographic relations, empathy, and ethics). She is currently Associate Professor in Anthropology at Aix Marseille University (AMU), and researcher at the Institute of Mediterranean, European and Comparative Ethnology (AMU-CNRS IDEMEC UMR 7307, France), in Aix-en-Provence, France. She may be reached at ghislaine.gallenga@univ-amu.fr 